Tropical Journal of Pharmaceutical Research April 2017; 16 (4): 889-896

ISSN: $1596-5996$ (print); 1596-9827 (electronic)

(C) Pharmacotherapy Group, Faculty of Pharmacy, University of Benin, Benin City, 300001 Nigeria.

All rights reserved.

Available online at http://www.tjpr.org

Original Research Article

http://dx.doi.org/10.4314/tjpr.v16i4.21

\title{
Anticancer activity of aqueous myrrh extract alone and in combination with cisplatin in HeLa cells
}

\author{
Wafaa S Ramadan ${ }^{1,2 \star}$, Khalid H Sait ${ }^{3}$ and Nisreen M Anfinan ${ }^{3}$ \\ ${ }^{1}$ Department of Anatomy, Faculty of Medicine, King Abdulaziz University, Jeddah, Saudi Arabia, ${ }^{2}$ Department of Anatomy, \\ Faculty of Medicine, Ain Shams University, Cairo, Egypt, ${ }^{3}$ Gynecology Oncology Unit, King Abdulaziz University Hospital, \\ Jeddah, Saudi Arabia
}

*For correspondence: Email: wramadhan@kau.edu.sa

Received: 31 October 2016

Revised accepted: 12 March 2017

\begin{abstract}
Purpose: To study the impact of an aqueous myrrh extract on the proliferation of cervical cancer cells in vitro.

Methods: First, $100 \mathrm{~g}$ of ground myrrh resin was boiled in $1000 \mathrm{~mL}$ of distilled water for $30 \mathrm{~min}$. Different components of the decoction were identified using gas chromatography-mass spectrometry and high-performance liquid chromatography. The effects of high $(20 \mu \mathrm{g} / \mathrm{mL})$ and low $(10 \mu \mathrm{g} / \mathrm{mL})$ concentrations of cisplatin, serial concentrations of myrrh $(20,40,60$, and $80 \mu \mathrm{g} / \mathrm{mL})$, and a combination of both were evaluated using cell proliferation assay, DNA fragmentation, and electron microscopy.

Results: All four myrrh concentrations decreased the viability of HeLa cells $(16.25 \% p<0.01)$. A significant further decrease occurred when myrrh was combined with $10 \mu \mathrm{g} / \mathrm{mL}$ cisplatin $(11.42 \% p<$ 0.01). This was confirmed by quantifying DNA fragmentation. Ultrastructurally, HeLa cells showed typical apoptosis after treatment with $10 \mu \mathrm{g} / \mathrm{mL}$ cisplatin or a high dose of myrrh. The use of $20 \mu \mathrm{g} / \mathrm{mL}$ cisplatin or the combined therapy resulted in cell necrosis with ruptured cell membranes and autophagosomes. The effect of combined therapy was more lethal than the effect of either of them alone.

Conclusion: Myrrh induces apoptosis and autophagy and enhances the activity of cisplatin in vitro. It is potentially a basis for further studies of other types of cancer cell. The clinical use of myrrh in the palliative therapy of human cervical carcinoma might be justified.
\end{abstract}

Keywords: Cervical cancer, Cell viability, Chemotherapy, DNA fragmentation, Myrrh, Cisplatin, Cell ultrastructure, HeLa cells

Tropical Journal of Pharmaceutical Research is indexed by Science Citation Index (SciSearch), Scopus, International Pharmaceutical Abstract, Chemical Abstracts, Embase, Index Copernicus, EBSCO, African Index Medicus, JournalSeek, Journal Citation Reports/Science Edition, Directory of Open Access Journals (DOAJ), African Journal Online, Bioline International, Open-J-Gate and Pharmacy Abstracts

\section{INTRODUCTION}

Platinating agents, including cisplatin (CDDP), are therapeutic agents used in many types of cancer affecting the gonads, female genital system, and head and neck [1]. CDDP is often administered after surgery or radiation [2]. Patients receiving platinating agents can experience dose-dependent side effects resulting in permanent toxicity and morbidity [3]. Cancer cells can also develop resistance through decreased drug vitality, which requires metabolic induction, or due to changes in apoptosis-related proteins $[4,5]$. 
Studies have examined the development of CDDP analogs to minimize its toxicity or resistance, which is crucial for the success of cancer chemotherapy [6]. Products extracted from species in the genus Commiphora have significant antibacterial, anti-inflammatory, and antitumor properties [7], in addition to their anti-proliferative effects in lung, pancreas, breast, and prostate cancers [8]. Therefore, this work evaluated the cytotoxic, apoptotic, autophagic, and chemosensitizing potential of the inexpensive medicinal plant, myrrh, alone and in combination with CDDP, on human cervical cancer cells in vitro using a cell proliferation assay, the quantification of DNA fragmentation, and electron microscopy.

\section{EXPERIMENTAL}

\section{Materials}

HeLa cells (CCL-81) were purchased from ATCC (USA) and Dulbecco's modified Eagle's medium (DMEM) from Biochrom (Germany). CDDP was provided by the Gynecology Oncology Unit in King Abdulaziz University Hospital (KAUH). CDDP (Ebewe Pharma, Austria, $50 \mathrm{mg} / 100 \mathrm{~mL}$ ) was prepared as a $3.3 \mathrm{mM}$ stock solution [9]. Myrrh resin was purchased from a local merchant, cleaned, and ground. MTT [3-(4,5dimethylthiazol-2-yl)-2,5-diphenyltetrazolium bromide)] was from Sigma-Aldrich.

\section{Preparation of aqueous extract of myrrh}

First, $100 \mathrm{~g}$ of clean ground myrrh resin was added to $1000 \mathrm{~mL}$ of distilled water. The mixture was heated to boiling at $100{ }^{\circ} \mathrm{C}$ for $30 \mathrm{~min}$. The decoction was centrifuged, filtered, frozen, and then lyophilized [10]. Then, $20 \mu \mathrm{g}$ of the powder was dissolved in DMEM with $10 \%$ fetal calf serum (FCS) before it was added to a monolayer of HeLa cells for $24 \mathrm{~h}$.

\section{Gas chromatography-mass spectrometry (GC-MS)}

The analysis was performed using a GCMSQP2010 plus (Japan) and a DB-5 column (30 m $\times 0.25 \mathrm{~mm}$ i.d.; film thickness $1.00 \mu \mathrm{m}$ ) (USA). A $1.0-\mu \mathrm{L}$ sample of the aqueous extract was injected using splitless mode. Details of the procedure have been reported elsewhere [11].

\section{High-performance liquid chromatography (HPLC)}

The aqueous extract was partitioned with diethyl ether using a separating funnel. The diethyl ether layer was evaporated under reduced pressure until dryness. The combined diethyl ether layers were evaporated and the resulting residue was dissolved in HPLC-grade methanol. Further technical details were as described previously [12].

\section{HeLa cell culture}

First, $10 \%$ fetal bovine serum (FBS) and 100 $\mu \mathrm{g} / \mathrm{mL}$ penicillin/streptomycin were added to the DMEM. For the culture and cytotoxicity experiments, $5 \times 10^{4} \mathrm{HeLa}$ cells/well were added to 96 -well plates in $5 \% \mathrm{CO}_{2}-95 \%$ air at $37{ }^{\circ} \mathrm{C}$. Triplicate wells were prepared.

\section{Cell proliferation assay}

To evaluate the proliferation of HeLa cells, the MTT assay was used. MTT is reduced to purple formazan by mitochondrial dehydrogenase, indicating normally functioning mitochondria [13]. HeLa cells were incubated with increasing doses of $\operatorname{CDDP}(2.5,5,10,20$, and $40 \mu \mathrm{g} / \mathrm{mL})$ for $24 \mathrm{~h}$, and cell viability was assayed. Three independent experiments were performed in quintuplicate. CDDP had a dose-dependent antiproliferative effect on cell viability. The $\mathrm{IC}_{50}$ of CDDP was $20 \mu \mathrm{g} / \mathrm{mL}$ after $24 \mathrm{~h}$ (Figure 1).

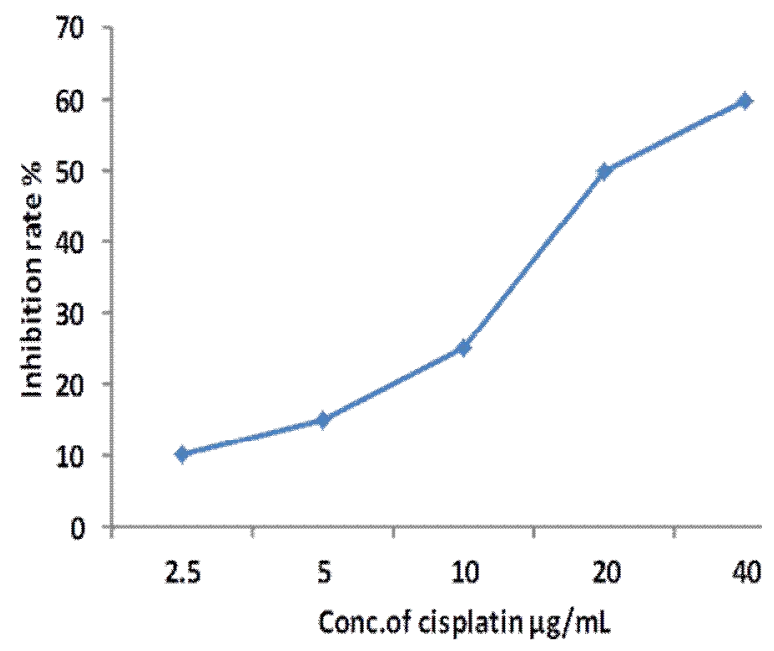

Figure 1: Dose- and time-dependent curve of the inhibition rate (\%) of cisplatin $(\mu \mathrm{g} / \mathrm{mL})$ on HeLa cells using MTT assay. Data are presented as mean $\pm S D$ of three independent experiments performed in quintuplicate. CDDP revealed a dose-dependent antiproliferative effect on cell viability. The IC50 of CDDP was $20 \mu \mathrm{g} / \mathrm{ml}$ after $24 \mathrm{hr}$ 
The medium was removed and replaced with high- $(20 \mu \mathrm{g} / \mathrm{mL})$ or low-dose $(10 \mu \mathrm{g} / \mathrm{mL})$ cisplatin solutions. Monolayer cells were also incubated with $20,40,60$, and $80 \mu \mathrm{g} / \mathrm{mL}$ of the aqueous myrrh extract. Another group was incubated with $10 \mu \mathrm{g} / \mathrm{mL}$ cisplatin and the serial doses of myrrh simultaneously. Cultured cells not subjected to any treatment acted as a control group. All wells were incubated for $24 \mathrm{~h}$ at $37{ }^{\circ} \mathrm{C}$ in $5 \% \mathrm{CO}_{2}-95$ $\%$ air. The absorption of the culture plates was measured at $570 \mathrm{~nm}$ after $24 \mathrm{~h}$ in MTT using an ELISA reader (Bio-Rad) and compared with the control cultures. All experiments were performed three times. The viability of the cultured cells was calculated as in Eq 1.

Viability $(\%)=\{(\mathrm{At}-\mathrm{Ac}) / \mathrm{Ac}\} 100$

where At and Ac are the absorbance of drugtreated and control samples, respectively.

\section{Quantitation of DNA fragmentation}

DNA fragmentation in cultured cells was tested using the diphenylamine technique [14]. Cells (13 $\times 10^{6}$ ) were incubated for $18 \mathrm{~h}$ with or without $\mathrm{CH}-11$ monoclonal antibody (100 ng/mL), collected, and washed with PBS. Total DNA was separated with $0.5 \mathrm{~mL}$ of lysis buffer $\{5 \mathrm{mM}$ Tris$\mathrm{HCl}, 2 \mathrm{mM}$ ethylenediaminetetraacetate (EDTA), $0.5 \%$ Triton $\mathrm{X}-100, \mathrm{pH} 8.0\}$, and the lysate was centrifuged to separate high- from low-molecularweight DNA. The cleaved DNA in the supernatant was precipitated with $5 \%$ trichloroacetic acid and the DNA fragments were quantified using spectrophotometry at $570 \mathrm{~nm}$ after adding diphenylamine.

DNA fragmentation (\%) was taken as the ratio of the amount of DNA in the supernatant to the total DNA in the supernatant and pellet, expressed as a percentage.

\section{Assessment of ultrastructural features}

The cell ultrastructure was studied using transmission electron microscopy, following the protocol of the King Fahd Medical Research Center at KAUH. When the cultured HeLa cells reached confluence, they were treated with trypsin diluted in phosphate-buffered saline (PBS) at a density of 200,000 cells per $\mathrm{mL}$, and fixed in $2.5 \%$ glutaraldehyde at room temperature for at least $2 \mathrm{~h}$ at $4^{\circ} \mathrm{C}$. The cells were centrifuged three times until a pellet formed. The pellet was processed as described previously [15]. Grids were examined and photographed with a transmission electron microscope (Philips CM 100) at $60 \mathrm{kV}$.

\section{Statistical analysis}

The data were analyzed using SPSS version 22 (IBM-USA). One-way analysis of variance (ANOVA) was used to determine the significance of differences. When equal variance was assumed, the least significant difference (LSD) $t$ test was applied. The data are presented as the mean \pm standard deviation (SD). $P<0.05$ was considered statistically significant.

\section{RESULTS}

The different components of the decoction of myrrh obtained using GC-MS and HPLC are listed in Table 1.

Table 1: Relative concentrations (\%) of different chemical components of myrrh decoction

\begin{tabular}{lc}
\hline Chemical category & $\begin{array}{c}\text { Composition } \\
(\%)\end{array}$ \\
\hline A-Cadinene & 3.6 \\
Cuminaldehyde & 1.8 \\
2-Methoxyfuranodiene & 3.2 \\
3-Epi-Alpha-Amyrin & 1.8 \\
Hydrocarbons & 0.4 \\
Phenols & 0.1 \\
\hline
\end{tabular}

\section{Cell viability}

There was a significant decrease in the viability of HeLa cells at all concen-trations of the aqueous extract of myrrh tested. Viability decreased by $16.25 \%$ on increasing the concentration from 20 to $80 \mu \mathrm{g} / \mathrm{mL}$. In addition, cisplatin at both 20 and $10 \mu \mathrm{g} / \mathrm{mL}$ caused significant decreases in cell viability $(50 \%$ and $36 \%$, respectively). The simultaneous combination of $10 \mu \mathrm{g} / \mathrm{mL}$ cisplatin and the serial concentrations of myrrh revealed a dosedependent decrease in cell viability. The greatest decrease was revealed upon combination with $80 \mu \mathrm{g} / \mathrm{mL}$ myrrh (11.42\%) and was $35.6 \%$ greater than that produced by the high concentration of cisplatin alone (Figure 2).

\section{DNA fragmentation}

To detect apoptosis, the DNA fragmentation was quantified. The use of myrrh alone increased the percentage of DNA fragmentation in a dosedependent manner. Cisplatin at 20 and $10 \mu \mathrm{g} / \mathrm{mL}$ induced 40.61 and $26.34 \%$ DNA fragmentation, respectively. Moreover, the combined therapy of cisplatin and aqueous extract of myrrh enhanced DNA fragmentation and appeared to be more effective than cisplatin alone (Figure 3 ). 


\section{Ultrastructural morphology}

The ultrastructure of HeLa cells was studied using transmission electron microscopy. The untreated HeLa cells had intact plasma membranes with many microvilli; the nucleus had prominent nucleoli; and viable mitochondria were observed in the cytoplasm (Figure 4a).

HeLa cells treated with $10 \mu \mathrm{g} / \mathrm{mL}$ Cisplatinwere typical apoptotic pyknotic cells with shrunken cytoplasm and condensed nuclear chromatin (Figure 4b). On increasing the dose of cisplatin to $20 \mu \mathrm{g} / \mathrm{mL}$, fragmentation of the nucleus, leakage of chromatin into the cytoplasm, development of autophago-somes, and rupture of the cell membrane were noted (Figure 4c). HeLa cells treated with the aqueous extract of myrrh contained clumps of nuclear chromatin and there was dilatation of the rough endoplasmic reticulum. Typical nuclear fragmentation was evident with higher doses (Figure $4 d$ to Figure $4 \mathrm{~g})$. Combining $10 \mu \mathrm{g} / \mathrm{mL}$ cisplatin and increasing serial doses of myrrh resulted in progressive condensation and leakage of chromatin, loss of integrity of the cytoplasmic organelles, and the presence of autophagosomes (Figure 4h Figure 4j). In addition, the combined therapy resulted in rupture of the plasma membrane of HeLa cells (Figure 4k).

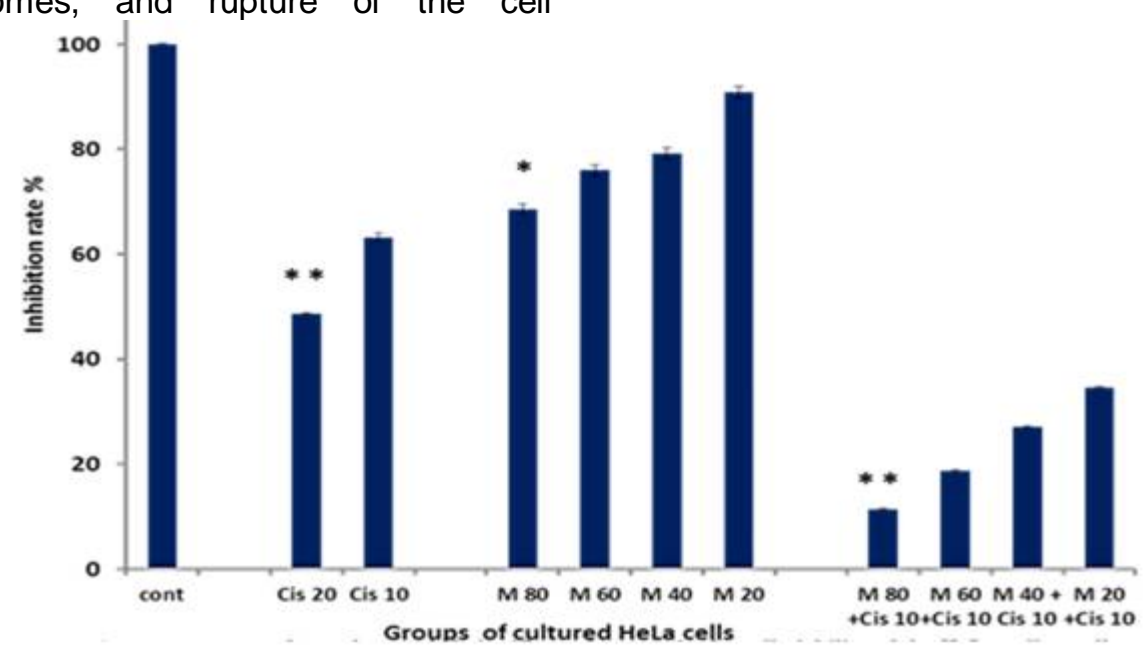

Figure 2: Cytotoxic effect of cisplatin and aqueous extract of myrrh on HeLa cells. The aqueous extract of myrrh caused a significant decrease in the viability of Hela cells at all concentrations. Simultaneous combination of $10 \mu \mathrm{g} / \mathrm{mL}$ cisplatin (Cis) and the serial concentrations of myrrh caused a dose-dependent decrease in cell viability. Untreated cells were used as a control (Cont). The results were analysed using one-way ANOVA followed by LSD post hoc test. Values are expressed as the mean $\pm S D$

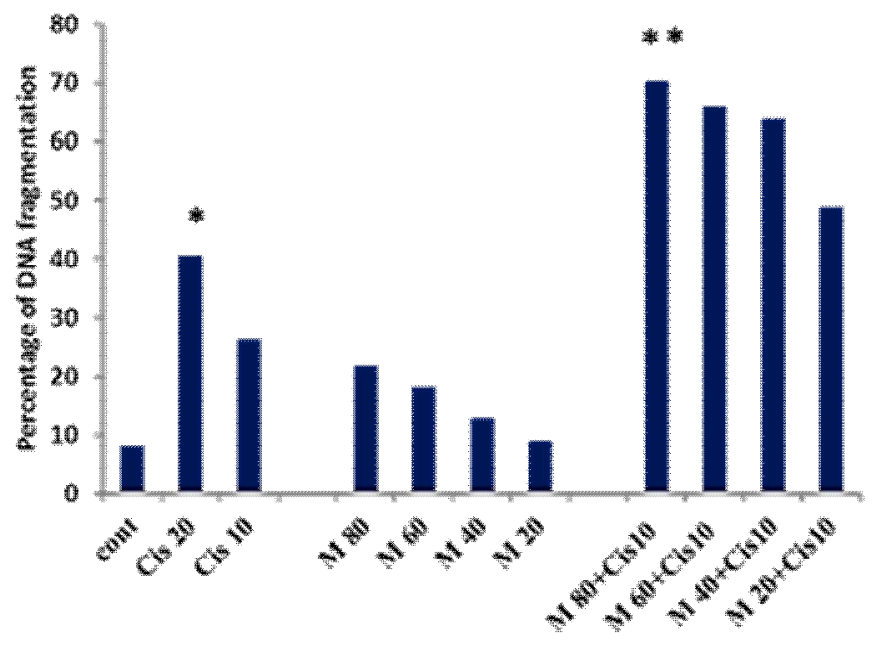

Groups of cultured Heta cells

Figure 3: Percentage of DNA fragmentation of hela cells using cisplatin (Cis) and aqueous myrrh $(\mathrm{m})$ extract separately and in combination. There was high DNA fragmentation with combination therapy with $80 \mu \mathrm{g} / \mathrm{ml}$ myrrh $(\mathrm{m})$ and $10 \mu \mathrm{g} / \mathrm{ml}$ Cis. Untreated cells were used as a control. The results were analysed using one-way ANOVA followed by LSD post hoc test. Values are expressed as the mean $\pm S D$ 

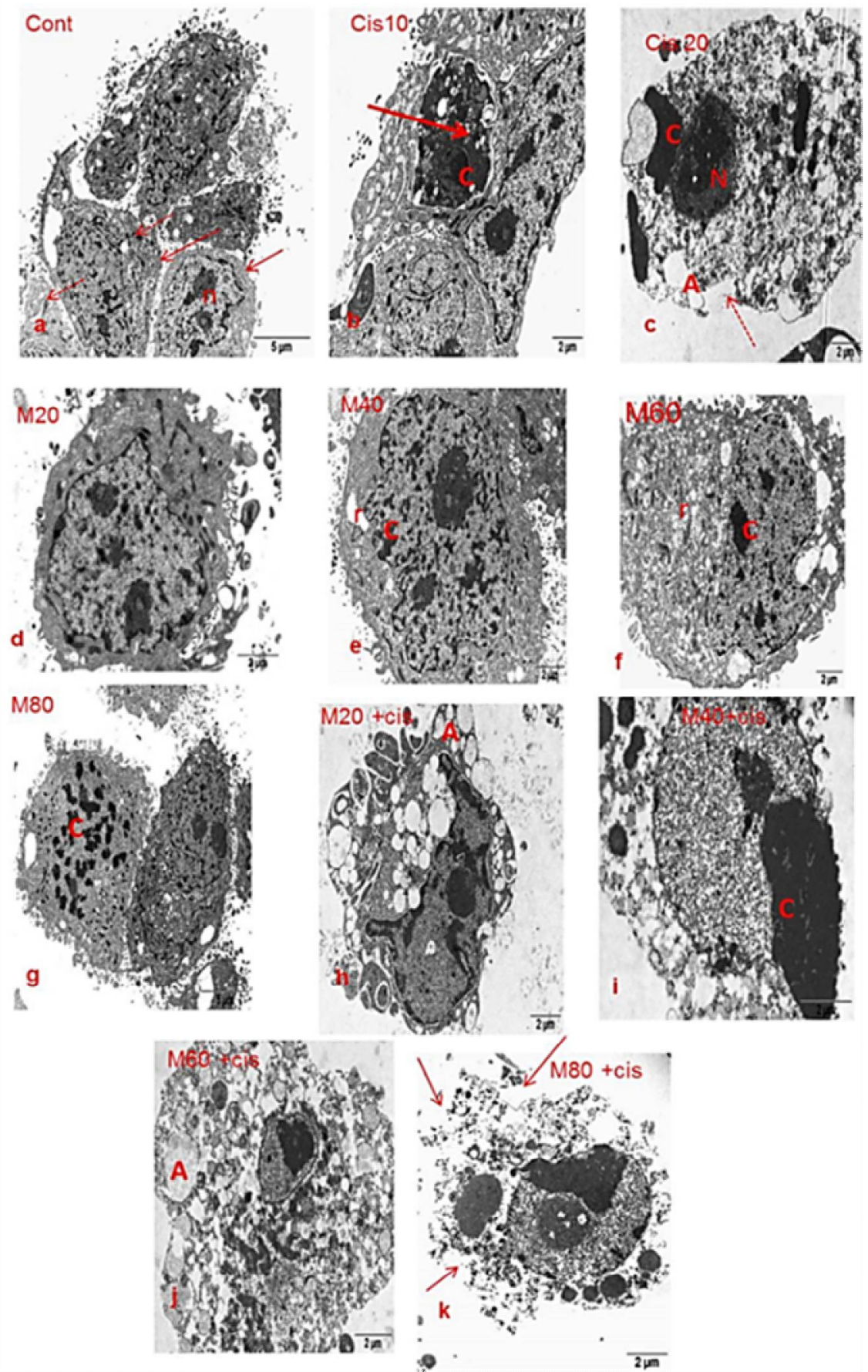

Figure 4: An electron micrograph showing the ultrastructural features of HeLa cells: (a) Untreated control group; (b, c) cells treated with 10 and $20 \mu \mathrm{g} / \mathrm{mL}$ cisplatin, respectively; (d-g) increasing doses of myrrh; and (h-k) both $10 \mu \mathrm{g} / \mathrm{mL}$ cisplatin and increasing doses of myrrh. The untreated Hela cells had intact plasma membranes and numerous microvilli (thin arrows). Nuclear membrane was intact and there were prominent nucleoli (n). The cytoplasm contained many viable mitochondria (dashed arrows) (a). (b, c). Treatment with 10 and $20 \mu g / m L$ cisplatin produced typical apoptotic pyknotic cells with shrunken cytoplasm and condensed nuclear chromatin $(N)$ (b), while in (c) there was fragmentation of the nucleus, leakage of chromatin into the cytoplasm, and cell membrane rupture. $(d-g)$ Treatment with increasing doses of myrrh resulted in clumps of nuclear chromatin and dilatation of the rough endoplasmic reticulum. (h-k) Treatment with $10 \mu \mathrm{g} / \mathrm{mL}$ Cisplatin and increasing serial doses of myrrh resulted in progressive condensation and leakage of chromatin (C), loss of integrity of the cytoplasmic organelles, and the presence of autophagosomes $(A) ;(k)$ shows rupture of the plasma membrane

\section{DISCUSSION}

This study used HeLa cells as a model to evaluate the therapeutic mechanism of myrrh in human cervical cancer by investigating its cytotoxic, apoptotic, and autophagic potential in comparison with CDDP. 
Myrrh alone caused a concentrationdependent decrease in the viability of HeLa cells. In addition, the concentration of CDDP had a profound effect, decreasing the cell viability to $11.42 \%$. Apoptotic effects were confirmed by the DNA fragmentation assay.

A previous study found that the majority of patients with cancer use complementary and alternative medicine (CAM); however, CAM is usually not effectively integrated with conventional oncology treatment (COT) [16].

The constituents of the decoction of myrrh included sesquiterpenes, such as a-cadinene, 2-methoxyfuranodiene, cuminaldehyde, and 3-epi-a-amyrin. In trials to induce cancer cell apoptosis, sesquiterpenes arrested the cell cycle at the $G_{0} / G_{1}$ phase in prostate cancer cells. Both the antiproliferative and the immune/inflamma-tory-modulating effects of myrrh were attributed to sesquiterpenes [17].

Physicochemical assays in vitro characterized these components as antioxidants. Nevertheless, they were described as cytotoxic. This was explained based on the cell membrane damage and permeability of its different layers, in addition to a decrease in the mitochondrial membrane potential leading to membrane depolarization [18] and a reduction in the $\mathrm{pH}$ gradient resulting in the seepage of cytochrome C, calcium ions, and proteins [19].

The ultrastructural morphology of HeLa cells revealed signs of apoptosis using either $(10 \mu \mathrm{g} / \mathrm{mL})$ cisplatin or myrrh, while features of necrotic cell death were obvious with the higher dose of cisplatin or the combined treatment. In accordance with these results, it was reported that cisplatin can induce either apoptosis or necrosis depending on the dose [20] and the metabolic and energy status of the cells [21].

Autophagosomes were also seen with the combined treatment. Autophagy may act as a therapeutic mechanism to suppress cancer or as an adaptive mechanism to protect cells from chemotherapy. The interaction between the microenvironment and autophagy is a complicated process [22]. The interactive link between apoptosis and autophagy has been documented and it has been reported that the same factors induce autophagy and apoptosis [23]. p53, a powerful motivator of apoptosis, can also drive autophagy. Autophagy increases DRAM, a direct p53 target gene [24]. In addition, activation of the $\mathrm{Pl} 3$ kinase/Akt pathway inhibits both apoptosis and autophagy [25]. Various biochemotherapeutic combinations have been developed to combine the cytotoxic action of cancer chemotherapy with substances that modulate the antitumor biological response. This is in addition to counteracting the suppressive effect of cancer chemotherapy on host immune/biological responses, which has a dominant effect in tumor progression [26]. Natural molecules isolated from myrrh have both immunostimulatory activity and anti-proliferative and antioxidant effects [27]. This could improve the efficacy and tolerability of standard anticancer therapies.

\section{CONCLUSION}

The findings of this study indicate that the use of myrrh alone and in combination with CDDP leads to apoptosis and autophagy. This is probably the basis for further studies of the effects on the survival of HeLa cells. The clinical use of myrrh in the palliative therapy of human cervical carcinoma may be justified. 


\section{DECLARATIONS}

\section{Acknowledgement}

This work was funded by Grants-in-Aid for Scientific Research from Scientific Chair of Prof. Abdullah Hussein Basalamah for Gynecological Cancer at King Abdulaziz University Hospital, Jeddah, Saudi Arabia.

\section{Conflict of Interest}

No conflict of interest associated with this work.

\section{Contribution of Authors}

The authors declare that this work was done by the authors named in this article and all liabilities pertaining to claims relating to the content of this article will be borne by them.

\section{Open Access}

This is an Open Access article that uses a funding model which does not charge readers or their institutions for access and distributed under the terms of the Creative Commons Attribution License (http://creativecommons.org/licenses/by/ 4.0) and the Budapest Open Access Initiative (http://www.budapestopenaccessinitiative.org/rea d), which permit unrestricted use, distribution, and reproduction in any medium, provided the original work is properly credited.

\section{REFERENCES}

1. Rabik CA, Dolan ME. Molecular mechanisms of resistance and toxicity associated with platinating agents." Cancer Treat Rev 2007; 33(1): 9-23.

2. Lee HN, Lee KH, Lee DW, Lee YS, Park EK, Park JS. Weekly cisplatin therapy compared with triweekly combination chemotherapy as concurrent adjuvant chemoradiation therapy after radical hysterectomy for cervical cancer. Int J Gynecol Cancer 2011; 21(1): 12836.

3. Leisching G, Loos B, Botha M, Engelbrecht AM. BCl2confers survival in cisplatin treated cervical cancer cells: circumventing cisplatin dose-dependent toxicity and resistance. J Trans/ Med 2015; 16: 13: 328.

4. Mehta K, Fok JY. Targeting transglutaminase-2 to overcome chemoresistance in cancer cells. In: Mehta K, Bates SE, Siddik ZH, Eds. Drug Resistance in Cancer Cells. Springer; New York, NY, USA: 2009; pp 95-114.

5. Rivlin N., Brosh R, Oren M, Rotter V. Mutations in the p53 tumor suppressor gene. Genes Cancer 2011; 2: 466-474.
6. Basu A, Krishnamurthy S. Cellular responses to Cisplatin-induced DNA damage. J Nucleic Acids 2010; 8: 201367.

7. AbdelGadir S, Ahmed IM. Commiphora myrrha and Commiphora africana essential oils. Journal of Chemical and Pharmaceutical Research 2014; 6(7): 151-156.

8. Sharma R. Recommendations on Herbs and Herbal Formula in Cancer Prevention. The Open Nutraceuticals Journal 2010; (3): 129-140

9. Hanigan $M H$, Deng $M$, Zhang L, Taylor PT (Jr), Lapus $M G$. Stress response inhibits the nephrotoxicity of cisplatin. Am J Physiol Renal Physiol 2005; 288(1): 125132

10. Mohamed AM, Metwally NS. Antiaflatoxinogenic activities of some plant aqueous extracts against Aflatoxin B1 induced renal and cardiac damage. J Pharmacol Toxicol 2009; 4(1): 1-16

11. Hashmi LS, Hossain MA, Weli AM, Al-Riyami Q, AlSabahi JN. Gas chromatography-mass spectrometry analysis of different organic crude extracts from the local medicinal plant of Thymus vulgaris $L$. Asian Pac $J$ Trop Biomed 2013; 3(1): 69-73.

12. Al-Sherif E, Hegazy AK, Gomaa NH, Hassan MO. Allelopathic effect of black mustard tissues and root exudates on some crops and weeds. Planta Daninha 2013; 31(1): 11-19

13. Lau CB, Ho CY, Kim CF, Leung KN, Fung KP, Tse TF, Chan $\mathrm{HH}$, Chow MS. Cytotoxic activities of Coriolus versicolor (Yunzhi) extract on human leukemia and lymphoma cells by induction of apoptosis. Life Sci 2004; 75(7): 797-808

14. Iwai K, Miyawaki T, Takazaki T, Konno A, Ohta K, Yachie A, Seki H, Taniguchi N. Differential expression of bcl-2 and susceptibility to anti-Fas-mediated cell death in peripheral blood lymphocytes, monocytes, and neutrophils. Blood 1994; 84: 1201-1208

15. Reynolds ES. The use of lead citrate at high $\mathrm{pH}$ as an electron-opaque stain in electron microscopy. J Cell Biol 1963; 17: 208-212

16. Menendez AG, Saied A, Espat NJ. Patient-reported experience combining complementary and alternative medicine (CAM) with conventional oncology treatment (COT). ASCO Annual Meeting (May 29 - June 2, 2015). J Clin Oncol 2015; 33(15 Suppl): 9625.

17. Tipton DA, Lyle B, Babich $H$, Dabbous $M K H$. In vitro cytotoxic and anti-inflammatory effects of myrrh oil B.on human gingival fibroblasts and epithelial cells. Toxicol in Vitro 2003; 17(3): 301-310.

18. Galluzzi L, Senovilla L, Vitale I, Michels J, Martins I, Kepp O, Castedo M, Kroemer G. Molecular mechanisms of cisplatin resistance. Oncogene 2012; 31(15): 18691883

19. Lissoni P. Prognostic markers in interleukin-2 therapy. Cancer Biother Radiopharm 1996; 11(5): 285-287.

20. Swift LH, Golsteyn RM. Cytotoxic amounts of cisplatin induce either checkpoint adaptation or apoptosis in a concentration dependant manner in cancer cells. Biol Cell 2016; 108(5): 127-148.

Trop J Pharm Res, April 2017; 16(4): 895 
21. Gonzalez VM, Fuertes MA, Alonso C, Perez JM. Is cisplatin-induced cell death always produced by apoptosis? Mol Pharmacol 2001; 59(4): 657-663

22. Gomes LR, Vessoni AT, Menck CF. Microenvironment and autophagy cross-talk: Implications in cancer therapy. Pharmacol Res 2016; 29: 107: 300-307.

23. Maiuri MC, Zalckvar E, Kimchi A, Kroemer G.Self-eating and self-killing: crosstalk between autophagy and apoptosis. Nat Rev Mol Cell Biol 2007; 8(9): 741-752.

24. Crighton $D$, Wilkinson $S$, O'Prey J, Syed $N$, Smith $P$, Harrison PR, Gasco M, Garrone O, Crook T, Ryan KM.
DRAM, a p53-Induced Modulator of Autophagy, is Critical for Apoptosis. Cell 2006; 126: 121-134.

25. Arico S, Petiot A, Bauvy C, Dubbelhuis PF, Meijer AJ, Codogno $P$, Ogier-Denis E. The tumor suppressor PTEN positively regulates macroautophagy by inhibiting the phosphatidylinositol 3-kinase/protein kinase $B$ pathway. J Biol Chem 2001; 276: 352

26. Lissoni P. Prognostic markers in interleukin-2 therapy. Cancer Biother Radiopharm 1996; 11(5): 285-287.

27. Grotenhermen F. Pharmacology of cannabinoids. Neuro Endocrinol 2004; 25(1-2): 14-23. 